\title{
Implementation Of E-Budgeting To Government Performance With Internal Control As A Moderation Variable
}

\author{
Gine Das Prena ${ }^{1}$ \\ Fakultas Ekonomi dan Bisnis \\ Universitas Pendidikan Nasional, \\ Indonesia \\ Email: ginedasfena@undiknas.ac.id
}

\author{
Putu Deviyanti Putri ${ }^{2}$ \\ Fakultas Ekonomi dan Bisnis \\ Universitas Pendidikan Nasional, \\ Indonesia
}

\begin{abstract}
This study aims are to examine the effect of implementation of e-budgeting on the government institution performance at the organizational level in the context of local government, this study purposes to find out how the role of internal control moderate the implementing e-budgeting with the government institution performance. Sample for this study is $76 \mathrm{E}$ budgeting system user at BPKAD (Badan Pengelola Keuangan dan Aset Daerah) and BAPPENDA (Badan Pendapatan Daerah) in Denpasar. anaysis using are Classical Assumption Test, MRA Test (Moderation Regression Analysis), and Partial Test (t-test). The test is carried out using the Sta tistical Package for Social Science (SPSS) program 25.0. The output of this 1) The implementation of E-budgeting had a significant effect on the performance of local government institution 2) The internal control as a moderating variable could not moderate the implementation of e-budgeting on the government institution performance.
\end{abstract}

Keywords: Implementation E-Budgeting; Government Institution Performance; Internal Control.

\section{Implementasi E-Budgeting Terhadap Kinerja Pemerintah Dengan Kontrol Internal Sebagai Variabel Moderasi}

\section{ABSTRAK}

Penelitian ini bertujuan untuk menguji pengaruh penerapan ebudgeting terhadapkinerja lembaga pemerintah di tingkat organisasi dalam konteks pemerintah daerah, penelitian ini bertujuan untuk mengetahui bagaimana peran kontrol internal memoderasi penerapan e-budgeting dengan kinerja lembaga pemerintah. Sampel untuk penelitian ini adalah 76 pengguna sistem penganggaran elektronik di BPKAD (Badan Pengelola Keuangan dan Aset Daerah) dan BAPPENDA (Badan Pendapatan Daerah) di Denpasar. Analisis yang digunakan adalah Uji Asumsi Klasik, Uji MRA (Analisis Regresi Moderasi), dan Uji Parsial (uji-t). Tes ini dilakukan dengan menggunakan program Paket Statistik untuk Ilmu Sosial (SPSS) 25.0. Output dari ini 1) Implementasi E-budgeting berpengaruh signifikan terhadap kinerja institusi pemerintah daerah 2) Kontrol internal sebagai variabel moderasi tidak dapat memoderasi implementasi e-budgeting pada kinerja institusi pemerintah.

Kata Kunci: Implementasi E-Budgeting; Kinerja Instansi Pemerintah; Kontrol Internal.

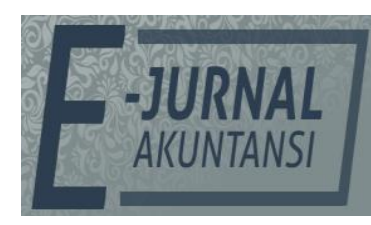

E-JA

e-Jurnal Akuntansi e-ISSN 2302-8556

Vol. 30 No. 5

Denpasar, Mei 2020

Hal.1318-1328

Artikel Masuk: 30 Maret 2020

Tanggal Diterima: 22 Mei 2020 


\section{INTRODUCTION}

Advances in technology in telecommunications and information technology ultimately make changes to the organizational structure, social and social relations. This has led to a change in community life activities in various sectors. One of them is the public sector that occurs within government organizations. The use of information and communication technology (Information and Communication Technology) from year to year is always experiencing growth. It can be seen every day from the use of information and communication is not limited to the field of trade or business, but also in the field of national defense, education, state government, social fields, and many more of course. The use of information and communication technology is used because it has advantages that are advantageous compared to using traditional methods of interacting. This also applies and requires a continuous organization developing improvements and changes.

The most important changes made by the organization are to achieve the goals desired by the organization, namely increasing productivity, improving services, increasing morale and capacity of members and public services carried out by the government. With the development of information and communication technology has created a model of public service that is done through E-Government (Gallego-Álvarez, Rodríguez-Domínguez, and GarcíaSánchez, 2016). E-Government carried out by the government starts from a simple form of service, namely the provision of information and computer-based data about the implementation of government and development as a form of transparency in public service The Government can also be used as a means of communication both internally among the SKPD (Satuan Kerja Perangkat Daerah) the Regional Work Unit and the community. With the existence of EGovernment, the government also provides innovation to a financial system that can facilitate the performance of government organizations, namely E-Budgeting.

In this era, where technology is growing rapidly and the application of technology to organizations like today can influence the performance in these organizations. (George Manning \& Kent Curtis 2017) Performance is a work achievement, actions, deeds, etc. (the accomplishment of work, acts, feat, etc.) in the sense that other Manning and Curtis are defining performance as the result of something that has been done. Performance is an overview of the achievements of the implementation of an activity/program/policy in achieving goals, objectives, missions, and the organization as stated in the formulation of the strategic organization (strategic planning) of an organization (Indra Bastian 2016). Performance measurement is essential in the management of the overall program because performance can be measured to encourage the achievement of such performance.

As in studies previously conducted by Farhangi (2017) and Kobelsky, Larosiliere, and Plummer (2016) that demonstrates the applicability technology within an organization can influence the performance of the organization. Whereas the $\mathrm{Wu}$ Jie study explained that not all organizations that apply technology can improve the performance of these organizations. The implementations of the E-budgeting system are to improve innovation and efficiency in budget management. In implementing the E-budgeting system, of 
course there is still an adjustment between the E-budgeting system and the performance of the government institution and also how the government institution is able to control the system.

The internal control system is a process that is designed to provide adequate confidence about the achievement of three categories of objectives which consist of the reliability of financial statements, effective and efficient. Based on the description above, researchers are interested in conducting a study entitled "Analysis of Implementation of E-Budgeting to Denpasar City Government Performance on Badan Pengelola Keuangan dan Aset Daerah (BPKAD) and Badan Pendapatan Daerah (BAPPENDA) with Internal Control as Moderation Variables.

Schillemans (2012) explained Stewardship theory has been developed out of dissatisfaction, with the theoretically postulated selfishness of agents and the ensuing and inescapable clash of interests between principals and agents. Stewardship theory seeks to understand the conditions under which agents are less likely to base their actions on self-interest, but rather take pleasure in serving collective goals or act as stewards to the interests of their principals. According to Slyke (2016), stewardship theory verifies behaviors and relationships ignored by the economic theories. The behavior on which stewardship theory is predicated includes collective, pro-organizational behavior that emphasizes goal convergence rather than self-interest. It says that the conflict of interests is always present, but it also emphasizes that the board members will always prioritize and pay attention of the interests of company or institution, for the sake of their position in the market of managers and also because it determines the perspective of their further promotion and development (Glinkowska 2015).

According to (Noerdiawan 2016) public sector budget is a process that is done by the sector organization the public to allocate resources the power it has in the need-to heal \& condition are not limited to (the process of allocation of res sources to unlimited demands). Meanwhile, according Mardiasmo (2014) public sector budget is an instrument of public accountability for the management and implementation of the finance programmed with public money. "PerformanceBased Budgeting is a budgeting system that is oriented towards organizational output and is very closely related to the organization's Vision, Mission and Strategic Plan. Performance-Based Budget allocates resources to programs not only to organizational units and uses measurement. As an indicator of organizational performance (Mardiasmo 2014).

E-budgeting is a budgeting system in the form of a computer program to assist in the budgeting process. With the implementation of a budgeting system, of course the performance in an organization will be influenced by the implementation of the system. LAN (2016:3) defines performance as an overview of the level of achievement of the implementation of an activity / program / wisdom in realizing the goals, objectives, mission and vision of the organization as stated in the formulation of strategic schemes (strategic schemes ) of an organization. On the previous research by Kobelsky, Larosiliere, E Plummer, (2013) the implementation of Information Technology (IT) in the organization can influence the performance of that organization. Based on Gunawan (2016), the realization of budget information transparency in this study can be seen through the budget 
information provided by the Surabaya City Government and the implementation of E-budgeting went well and in accordance with standard operational procedures.

$\mathrm{H}_{1}$ : Implementation of E-budgeting Implementation has a positive effect on the Performance of Local Government Institution.

Internal control system defined as an integral process of actions and activities carried out by management (executives) and their staff to provide adequate assurance or confidence in the achievement of organizational objectives through effective and efficient activities, reliability, financial reporting, security of state assets and observance laws and regulations (Nuramalia Hasanah 2017).

Menurut Yasmin, (2018) Internal control system is an integrated process within an organization to guarantee and ensure the achievement of organizational goals through effective and efficient activities through coordinated and temporary methods and measures meant by the Government Internal Control System SPIP (Sistem Pengendalian Internal Pemerintah) is an internal control system that is held thoroughly within the central government and local government environment.

Internal control systems are very important in an organization to achieve the goals set. Good internal control will produce good employee performance. With internal control, it will improve organizational performance, provide opinions on organizational performance, and provide recommendations to leaders to make corrections to the problem of performance achievement. However, internal control cannot affect the implementation of a system. As in Toufan Dharmawan's research, Supriatna (2016) internal control can affect the government institution performance, but in Rosalina (2016) research internal control cannot moderate the implementation of the system information technology to local governments.

$\mathrm{H}_{2}$ : Internal control can moderate the implementation of e-budgeting on the performance of local government institution.

\section{RESEARCH METHODS}

Population in this study are employees of the Regional Financial and Asset Management Institution BPKAD (Badan Pengelola Keuangan dan Aset Daerah) of Denpasar City and the Regional Revenue Institution BAPENDA (Badan Pendapatan Daerah) of the Denpasar City Government who use E-budgeting in their work. On BPKAD Denpasar City in the planning, data, reporting and financial sub-sectors, the budget sector as well as the treasury, accounting, and reporting fields totaling 61 people. On BAPENDA Denpasar City Government in the planning and financial sub-division totaling 15 people. The total population is 76 people who use the E-budgeting system at their jobs. Based on this study because the total population is not greater than 100 respondents, the authors take $100 \%$ of the population in BPKAD and BAPENDA, Thus the use of the entire population without having to withdraw the research sample as an observation unit is called the census technique.

Data collection techniques used in this study were questionnaires. The questionnaire was measured using a Likert scale. Likert scale is a scale used to measure the attitudes, opinions, and perceptions of a person or group of people 
about a phenomenon (Juliandi, 2013: 72). This study uses a number of statements $1-5$.

Instruments in a study must meet valid and reliable requirements. For this reason, it is necessary to test the instrument through a validity test and a reliability test. According to (sugiyono 2016) a valid instrument means the measuring instrument used to obtain the data is valid. Valid means that the instrument used must be able to measure what should be measured. According to (sugiyono 2016) Reliability is a term used to indicate the extent to which a measurement result is relatively consistent if the measurement is repeated twice or more, reliability is an index that shows the extent to which a measuring tool can be trusted or reliable. Validity and reliability testing can be done using the Statistical Product and Service Solution (SPSS) program.

The data in this study were analyzed with the classical assumptions, MRA Test (Moderated Regression Analysis), and Partial Test (t Test). The classic assumption test is an analysis conducted to assess whether in a linear regression model of Ordinary Least Square (OLS) there are classic assumption problems. In this study normality, and heteroscedasticity, and auto correlation tests were performed using the help of the Statistical Product and Service Solution (SPSS) program. Normality Test aims to see whether the value of confounding variables or residuals is normally distributed or not. A good regression model is to have a normally distributed residual value. Multicollinearity Test aims to see whether or not there is a high correlation between independent variables or independent variables in a multiple linear regression model. The heteroscedasticity test aims to see whether there is an unequal variance from the residue of one observation to another. If the variance from the residue from one observation to another is fixed, then it is called Heteroscedasticity.

Interaction test or often called Moderated Regression Analysis (MRA) is a special application of linear multiple regression where the regression equation contains interaction elements (multiplication of two or more independent variables). The formulas used in the regression equation are:

Information:

$$
\mathrm{Y}=\alpha+\beta 1 \mathrm{X} 1+\beta 2 \mathrm{X} 2+\beta 3 \mathrm{X} 1 \mathrm{X} 2+\varepsilon
$$

$\mathrm{Y} \quad=$ the dependent variable of the government institution performance

$\mathrm{X} 1=$ Independent variable implementation of E-budgeting

$\mathrm{X} 2=$ Internal Control moderation variable

$\mathrm{X} 1 . \mathrm{X} 2$ = Interaction between the independent variables of E-budgeting implementation and the Internal Control moderating variable

a $\quad=$ Constant

$\beta \quad=$ Regression coefficient (increase or decrease value)

$\varepsilon \quad=$ Error

\section{RESULTS AND DISCUSSION}

Validity Test is used to ensure that each questionnaire is valid and able to measure what would be to measured. The method used in the measurement of validity using the SPSS application version 25.0. Each questionaire that use in this study is eligible and declared valid. In the other hand the reliability test is carr ied 
out that the questionaire used can be trusted cause all Cronbach alpha values for each variable are greater than 0.7 , that can be stated the questionaire are reliable.

For Data Analysis because in this study using parametric statistics with regression models, it is necessary to do a classic assumption test that includes the normality test, multicollinearity test, and heterocedasticity test. To analyze the classical assumption test is carried out using the Statistical Package for Social Science (SPSS) program 25.0 for Windows. The classic assumption test can be explained as follows:

Normality test aims to test whether in the residuals of the regression model made normal distribution or not. this study have good regression model cause model of this study shown a normal or near normal residual distribution. The test that used is the Kolmogorov-Smirnov (K-S) test. Data of this study said to be normally distributed cause the significance level is 0.099 that greater than 0.05 .

Multicollinearity test aims to find out whether there is a correlation between independent variables in a regression model. Regression model for this study said to be good cause there was no correlation between the independent variables. For this study detection the presence or absence of correlation between independent variables, it can be seen at the tolerance value that is above 0.1 and the value of the variance inflation factor (VIF) is below 10, which means that there are no symptoms of multicollinearity.

Heteroscedasticity test aims to test in the regression model that there is an unequal variance from the residuals of one observation to another. This heteroscedasticity test occurs or not is to look at the plot graph between the predicted value of the dependent variable, ZPRED and the residual SRESID. For this study there is no heteroscedasticity because there is no clear pattern, and the points spread above and below the number 0 on the $Y$ axis. The data are rendomly distributed and do not from a spesific pattern at the scatterplot and the point are spread below and above point 0 .

Table 1. Model Summary MRA

\begin{tabular}{|c|c|c|c|c|c|}
\hline \multirow{2}{*}{\multicolumn{2}{|c|}{ Model }} & & & & \\
\hline & & R Square & $\begin{array}{ll}\text { Adjusted } & \mathrm{R} \\
\text { Square } & \end{array}$ & $\begin{array}{l}\text { Std. Error of } \\
\text { the Estimate }\end{array}$ & Durbin-Watson \\
\hline 1 & & 70 & .552 & 1.765 & 2.094 \\
\hline
\end{tabular}

a. Predictors: (Constant), Moderated $X^{\star} Z$, E-Budgeting, Internal Control

b. Dependent Variable: Government Performance

Source: Research Data, 2020

From the Table 1 . shows that the adjusted R Square coefficient is $57 \%$, which means that $57 \%$ of the performance variables of government institution can be explained by the variable implementation of e-budgeting, internal control, and moderation. While the rest of $100 \%-57 \%=43 \%$ can be explained by other factors outside the model. 
Table 2. Anova MRA

\begin{tabular}{llrrrrr}
\hline \multicolumn{1}{l}{ Model } & \multicolumn{1}{c}{$\begin{array}{c}\text { Sum of } \\
\text { Squares }\end{array}$} & df & \multicolumn{1}{c}{$\begin{array}{c}\text { Mean } \\
\text { Square }\end{array}$} & F & Sig. \\
\hline 1 & Regression & 305.097 & 3 & 101.699 & 32.658 & $.000^{\mathrm{b}}$ \\
& Residual & 230.441 & 74 & 3.114 & & \\
& Total & 535.538 & 77 & & & \\
\hline
\end{tabular}

Source: Research Data, 2020

Based on the Table 2. shows that the magnitude of the coefficient $\mathrm{F}=$ 32.658 and the coefficient Sig. $=0,000<a=0.05$ then H0 is rejected. Means the regression obtained can be used to predict government institution performance. On the other hand, the implementation of e-budgeting, internal control, and moderate together affect the government institution performance.

Table 3. Coefficient MRA

\begin{tabular}{|c|c|c|c|c|c|c|}
\hline \multirow{2}{*}{\multicolumn{2}{|c|}{ Model }} & \multicolumn{2}{|c|}{$\begin{array}{l}\text { Unstandardized } \\
\text { Coefficients }\end{array}$} & \multirow{2}{*}{$\begin{array}{c}\begin{array}{c}\text { Std. } \\
\text { Coefficients }\end{array} \\
\text { Beta }\end{array}$} & \multirow[t]{2}{*}{$\mathrm{t}$} & \multirow[t]{2}{*}{ Sig. } \\
\hline & & $\mathrm{B}$ & Std. Error & & & \\
\hline \multirow[t]{4}{*}{1} & (Constant) & -11.634 & 11.005 & & -1.057 & .294 \\
\hline & E-Budgeting & .501 & .249 & .945 & 2.013 & .048 \\
\hline & $\begin{array}{l}\text { Internal } \\
\text { Control }\end{array}$ & 496 & .239 & 1.068 & 2.075 & .041 \\
\hline & $\begin{array}{l}\text { Moderated } \\
X^{*} Z\end{array}$ & -.007 & .005 & -1.157 & -1.281 & .204 \\
\hline
\end{tabular}

a. Dependent Variable: Government Performance

Source: Research Data, 2020

The regression equation are:

$$
Y=-11,634+0,501 X_{1}+0,496 X_{2}+-0,007 X_{1} X_{2}+\varepsilon
$$

A constant value of $-11,634$ means that if the implementation of ebudgeting, internal control, and the relationship between the implementation of e-budgeting and constant internal control, the performance of government agencies decreases by 11,634 units. Regression coefficient of the implementation of e-budgeting (X1) of 0.501 means that if the implementation of e-budgeting increases by 1 unit assuming the other variables are constant then the performance of government agencies increases by 0.501 units. Internal control regression coefficient (X2) of 0.496 means that if internal control increases by 1 unit with the assumption that other variables are constant, then internal control increases by 0.496 units. The $\mathrm{X} 1 \mathrm{X} 2$ regression coefficient value of -0.007 indicates that if the relationship between the implementation of e-budgeting with internal control increases by 1 unit, the employee's performance decreases by 0.007 units.

Table 3. shows that of the three independent variables, the E-budgeting and Internal Control variables are significant (Sig. $<0.05)$ while the moderate variable is not significant (Sig.> 0.05). Thus, it can be stated that the Internal Control variable is not a Moderating variable, because internal control cannot moderate the implementation of e-budgeting on government institution performance. 
Table 4. Partial Test (t Test)

\begin{tabular}{|c|c|c|c|c|c|c|}
\hline \multirow{2}{*}{\multicolumn{2}{|c|}{ Model }} & \multicolumn{2}{|c|}{$\begin{array}{l}\text { Unstandardized } \\
\text { Coefficients }\end{array}$} & \multirow{2}{*}{$\begin{array}{c}\begin{array}{c}\text { Std. } \\
\text { Coefficients }\end{array} \\
\text { Beta }\end{array}$} & \multirow[t]{2}{*}{$t$} & \multirow[t]{2}{*}{ Sig. } \\
\hline & & $\mathrm{B}$ & Std. Error & & & \\
\hline \multirow[t]{3}{*}{1} & (Constant) & 2.239 & 1.945 & & 1.151 & .253 \\
\hline & E-Budgeting & .193 & .065 & .365 & 2.968 & .004 \\
\hline & $\begin{array}{l}\text { Internal } \\
\text { Control }\end{array}$ & 199 & .057 & .428 & 3.482 & .001 \\
\hline
\end{tabular}

a. Dependent Variable: Government Performance

Source: Research Data, 2020

This test is carried out to determine the effect of each independent variable, implementation e-budgeting and internal control on the dependent variable, Government Institution performance. The proposed hypothesis can be accepted if the sig value < of the value $a(0.05)$ and $t$ count higher than $t$ table it can be accepted. This test was conducted to answer the hypotheses in this research. Partial test results can be seen in Table 4 which found the significance value of the variable E-Budgeting implementation of 0.04 smaller than $\alpha=0.05$, it can be concluded that the implementation of E-Budgeting has a significant effect on the government institution performance. Internal Control variable of 0.01 is smaller than $\alpha=0.05$, it can be concluded that Internal Control has a significant effect on the government institution performance. And based on Table 4 the Internal Control variable of $t=-1.281$ with a significance of 0.204 . The significance value is greater than $\alpha=0.05$, which indicates that the internal control moderating variable cannot moderate the effect of e-budgeting implementation on employee performance.

The Effect of E-Budgeting implementation on the performance of local government institution shown from test results shown the significance value of the e-budgeting implementation variable of 0.04 smaller than $\alpha=0.05$, it can be concluded that the implementation of e-budgeting has a significant effect on the government institution performance, then the hypothesis is accepted. The accepted research hypothesis can be based on the utilization and effectiveness of the implementation of e-budgeting so that it can help productivity in the budget design.

The results of this study are in line with research conducted by Kobelsky, Larosiliere (2016) who stated Information Technology has a positive impact on performance and the effect is comparable. That has significant implications for research investigating the effects of investment in IT on organizational performance and for stakeholders. as well as research conducted by the Refrensi from Rosalina (2016) which states E-budgeting implementation Affects the performance of Surabaya City institution.

This study is also consistent with the theory of New Public Management, which states that public / government management, the practices work Applies private sector to the public sector to create efficiency and effectiveness of local government so that public welfare performance will be created. Thus, the implementation of e-budgeting can improve efficiency and effectiveness in increasing the performance of local government institution. 
The internal control as the moderating variable for the effect of Ebudgeting on the goverment institution performance shown the significance value of the internal control variable of 0.204 is greater than $a=0.05$, it can be concluded that the Internal Control variable is equal to the value of $t=-1.281$ with a significance of 0.204 . The significance value is greater than $a=0.05$, which indicates that the internal control moderating variable cannot moderate the implementation of e-budgeting to employee performance, the hypothesis is rejected. This research hypothesis is rejected because it can be caused by the environmental control and risk assessment that has not been implemented properly, so that internal control variables cannot moderate the implementation of e-budgeting on the performance of government agencies.

The results of this study support the results of previous research by Rosalina (2016) which states that internal control does not moderate e-budgeting and the performance of the Surabaya City government institution.

The results of this study are not in line with research conducted by Toufan Dharmawan, Supriatna (2016) which states that the Implementation of the Internal Control System can affect the government institution performances and also has been in accordance with the principles of good governance.

The results of this study are not in line with the theory of stewardship where the general objective of internal control is efficiency and effectiveness of operations. So, when internal control is implemented it will encourage the effective and efficient use of resources to achieve the goals and objectives of the organization. So, the competence of institution performance in producing the quality in implementation e-budgeting cannot strengthened by internal control.

\section{CONCLUSION}

Based on the results of data analysis and discussion of the Analysis of Implementation of E-Budgeting to Denpasar City Government Performance on the Regional Financial and Asset Management Agency (BPKAD) and the Regional Revenue Agency (BAPPENDA) with Internal Control as Moderation Variables, the conclusions can be drawn as a few things, The results of the study found that the implementation of E-budgeting had a partially significant effect on the performance of the local government agencies, it based on the understanding that the implementation of e-budgeting drive efficiency and help in the preparation of the APBD so that it can have a positive effect on the performance of government agencies. Internal control as a moderating variable could not moderate the implementation of e-budgeting to the performance of government agencies. This because the internal control system already has a clear internal control system structure and procedures but it still has no significant effect on the implementation of e-budgeting on the performance of government agencies.

\section{REFERENCE}

Bastian, Indra (2016). Akuntansi Sektor Publik. Badan Penerbit Fakultas Ekonomi UGM, Yogyakarta.

Ekanayeka Athula (2018). Accounting Inscriptions and Goverment of Public in Developing Countries. Journal Of Government Performance vol 6 no 2 
pp 83-98

Emad Ahmed Abu (2017). E Goverment Contribution to Better Performance Public Sector. Journal Of Association For Computing Machinery. Vol 7 no 1

Encarani A (2015). Toword Quality E Goverment in Public Soctor.Managing Service Quality Journal. 151,6-23

Gallego-Álvarez, Isabel, Luis Rodríguez-Domínguez, and Isabel María GarcíaSánchez (2016). "Are Determining Factors of Municipal E-Government Common to a Worldwide Municipal View? An Intra-Country Comparison." Government Information Quarterly 27 (4): 423-30. https://doi.org/10.1016/j.giq.2016.12.011.

George Manning; Kent Curtis (2017). Performance: Managing for Excellence. Cincinnati, Ohio: Vista Systems.

Gil-García, J. Ramón, and Theresa A. Pardo (2015). "E-Government Success Factors: Mapping Practical Tools to Theoretical Foundations." Government Information Quarterly 22 (2): 187-216. https://doi.org/10.1016/j.giq.2005.02.001.

Glinkowska, Beata (2015). "Classical and Modern Concepts of Corporate Governance (Stewardship Theory and Agency Theory)" 19 (2): 84-92. https://doi.org/10.1515/manment-2015-0015.

Gunawan, Dimas Rizky (2016). "Penerapan Sistem E-Budgeting Terhadap Transparansi Dan Akuntabilitas Keuangan Publik (Studi Pada Pemerintah Kota Surabaya)." Jurnal Akuntansi 8 (1): 72-102.

Hepu Deng.(2018).Evaluating the Performance of E Goverment in Developing Contries a Public Value Perspective. Journal of System Information and Internet Research Vol 28 no 1

Indra Bastian (2016). Akuntansi Sektor Publik Di Indonesia. Yogyakarta: BPFE.

Kaifeng Yang.(2017). E Government For Better Performance. International Journal of Public Administration Pp 197-217

Karunasena Kanishka, Mohini Singh (2018). Measuring The Public Value of E Government A Case Study From Sri Lanka. Journal Of Transforming Goverment Vol 5 no 1 pp 81-99

Kobelsky, Kevin, Gregory Larosiliere, and Elizabeth Plummer (2016). "International Journal of Accounting Information Systems The Impact of Information Technology on Performance in the Not-for-pro Fi t Sector." International Journal of Accounting Information Systems. https://doi.org/10.1016/j.accinf.2013.02.002.

Mardiasmo (2016). Akuntansi Sektor Publik. Yogyakarta: Andi.

- - - . (2014). Akuntansi Sektor Publik. Yogyakarta: Andi.

Noerdiawan, Deddi. (2016). Akuntansi Sektor Publik. Jakarta: Salemba Empat.

Noviandi Erhan (2017). Evaluating of E Government (Case Study of the Implementation of Electronic Monitoring and Evaluation. Journal of Public Administration Studies Vol 2 no 2

Nuramalia Hasanah, Achmad Fauzi. (2017). Akuntansi Pemerintahan. Bogor: IN MEDIA.

Rama Andika Thio Rahman, Gugus Irianto, Rosidi. (2018). "Analisis Implementasi E-Budgeting Dengan Menggunakan Model Cipp Pada 
Pemerintah Provinsi Dki Jakarta." Journal Sistem Informasi (Journal of Information System) 14 (2): 53-63.

Reddick G Christopher (2015) Public Sector Transformation Through E Government Experiences from Europe and North America. Routledge Sub Of International Thomson Org.

Schillemans, Thomas. (2012). "Moving Beyond The Clash of Interests : On Stewardship Theory and the Relationships between Central Government Departments and Public Agencies." Public Management Review 15 (2015): 37-41. https://doi.org/10.1080/14719037.2012.691008.

Slyke, David M. Van. (2016). “Agents or Stewards: Using Theory to Understand the Government-Nonprofit Social Service Contracting Relationship." Journal of Public Administration Research and Theory 17 (2): 157-87. https://doi.org/https://doi.org/10.1093/jopart/mul012.

sugiyono. (2016). "Metode Penelitian Pendidikan (Kuantitatif Kualitatif Dan R \& D)." Bandung: Alfabeta. https://doi.org/10.1164/rccm.200409-1267OC.

Venkatramans (2014). Performance Evaluation of E Government Services Emperical Study In Jordan. International Journal Toronto Pp 512-536

Yasmin. (2018). "Sistem Pengendalian Intern Pemerintah Dalam Pungukuran Kinerja Pemerintahan Di Kabupaten Bandung." JIAFE (Jurnal Ilmiah Akuntansi Fakultas Ekonomi) 4 (1): 101-16. https://journal.unpak.ac.id/index.php/jiafe. 